\title{
Carboxydothermus siderophilus sp. nov., a thermophilic, hydrogenogenic, carboxydotrophic, dissimilatory Fe(III)-reducing bacterium from a Kamchatka hot spring
}

\author{
Tatiana V. Slepova, ${ }^{1}$ Tatyana G. Sokolova, ${ }^{1}$ Tatyana V. Kolganova, ${ }^{2}$ \\ Tatyana P. Tourova ${ }^{1}$ and Elizaveta A. Bonch-Osmolovskaya ${ }^{1}$ \\ ${ }^{1}$ Winogradsky Institute of Microbiology, Russian Academy of Sciences, Prospect 60 Let Oktyabrya \\ 7/2, 117312 Moscow, Russia \\ ${ }^{2}$ Bioengineering Center, Russian Academy of Sciences, Prospect 60 Let Oktyabrya 7/1, 117312 \\ Moscow, Russia
}

Correspondence

Tatiana V. Slepova

slepysh@gmail.com

\begin{abstract}
A novel anaerobic, thermophilic, Fe(III)-reducing, CO-utilizing bacterium, strain $1315^{\top}$, was isolated from a hot spring of Geyser Valley on the Kamchatka Peninsula. Cells of the new isolate were Gram-positive, short rods. Growth was observed at $52-70{ }^{\circ} \mathrm{C}$, with an optimum at $65{ }^{\circ} \mathrm{C}$, and at $\mathrm{pH}$ 5.5-8.5, with an optimum at $\mathrm{pH}$ 6.5-7.2. In the presence of $\mathrm{Fe}$ (III) or 9,10anthraquinone 2,6-disulfonate (AODS), the bacterium was capable of growth with $\mathrm{CO}$ and yeast extract $\left(0.2 \mathrm{~g} \mathrm{I}^{-1}\right)$; during growth under these conditions, strain $1315^{\top}$ produced $\mathrm{H}_{2}$ and $\mathrm{CO}_{2}$ and $\mathrm{Fe}(\mathrm{II})$ or $\mathrm{AQDSH}_{2}$, respectively. Strain $1315^{\top}$ also grew by oxidation of yeast extract, glucose, xylose or lactate under a $\mathrm{N}_{2}$ atmosphere, reducing $\mathrm{Fe}(\mathrm{III})$ or AQDS. Yeast extract $\left(0.2 \mathrm{~g} \mathrm{I}^{-1}\right)$ was required for growth. Isolate $1315^{\top}$ grew exclusively with $\mathrm{Fe}(\mathrm{III})$ or $\mathrm{AQDS}$ as an electron acceptor. The generation time under optimal conditions with $\mathrm{CO}$ as growth substrate was $9.3 \mathrm{~h}$. The $\mathrm{G}+\mathrm{C}$ content of the DNA was $41.5 \pm 0.5 \mathrm{~mol} \%$. 16S rRNA gene sequence analysis placed the organism in the genus Carboxydothermus ( $97.8 \%$ similarity with the closest relative). On the basis of physiological features and phylogenetic analysis, it is proposed that strain $1315^{\top}$ should be assigned to a novel species, Carboxydothermus siderophilus sp. nov., with the type strain $1315^{\top}\left(=\right.$ VKPM $9905 B^{\top}=$ VKM B- $2474^{\top}=$ DSM $\left.21278^{\top}\right)$.
\end{abstract}

Hydrogenogenic CO-oxidizing anaerobes represent a physiological group of thermophilic prokaryotes able to grow on $\mathrm{CO}$, producing hydrogen and $\mathrm{CO}_{2}$ according to the reaction $\mathrm{CO}+\mathrm{H}_{2} \mathrm{O} \rightarrow \mathrm{CO}_{2}+\mathrm{H}_{2}\left(\Delta \mathrm{G}^{\prime}{ }_{0}=-20 \mathrm{~kJ} \mathrm{~mol}{ }^{-1}\right)$. They have been found in various hydrothermal environments, both terrestrial and submarine (Sokolova et al., 2007). Representatives of another physiological group of prokaryotes, $\mathrm{Fe}$ (III) reducers, are also widespread in thermal habitats (Slobodkin, 2005). An assumption has been made that these two types of chemolithotrophic growth (hydrogenogenic carboxydotrophy and ferric iron reduction) often co-exist in hydrothermal environments (Sokolova et al., 2007). The genera Carboxydothermus, Thermosinus, Thermincola and Thermolithobacter consist of hydrogenogenic carboxydotrophic and $\mathrm{Fe}$ (III)-reducing species (Svetlichny et al., 1991; Slobodkin et al., 2006; Sokolova et al., 2004, 2005, 2007; Zavarzina et al., 2007). One of these

Abbreviation: AQDS, 9,10-anthraquinone 2,6-disulfonate.

The GenBank/EMBL/DDBJ accession number for the $16 \mathrm{~S}$ rRNA gene sequence of strain $1315^{\top}$ is EF542810. organisms, Thermosinus carboxydivorans, grows on CO, producing molecular hydrogen, and simultaneously reduces $\mathrm{Fe}(\mathrm{III})$ to $\mathrm{Fe}$ (II) (Sokolova et al., 2004). Here, we report the isolation of a novel thermophilic, hydrogenogenic, carboxydotrophic, dissimilatory $\mathrm{Fe}(\mathrm{III})$-reducing bacterium from a Geyser Valley hot spring (Kamchatka Peninsula).

Strain $1315^{\mathrm{T}}$ was isolated from a sample of pink filaments from a hot spring with a temperature of $72{ }^{\circ} \mathrm{C}$ and a $\mathrm{pH}$ of 8.4. For enrichment and isolation of anaerobic carboxydotrophic bacteria, the following basal medium was used (per litre): $0.66 \mathrm{~g} \mathrm{NH} 4 \mathrm{Cl}, 0.16 \mathrm{~g} \mathrm{MgCl}_{2} \cdot 6 \mathrm{H}_{2} \mathrm{O}, 0.1 \mathrm{~g}$ $\mathrm{CaCl}_{2} \cdot 6 \mathrm{H}_{2} \mathrm{O}, 0.33 \mathrm{~g} \mathrm{KCl}, 0.5 \mathrm{~g} \mathrm{KH}_{2} \mathrm{PO}_{4}, 1 \mathrm{ml}$ trace element solution (Kevbrin \& Zavarzin, 1992) and $1 \mathrm{ml}$ vitamin solution (Wolin et al., 1963). After boiling, the medium was flushed with $\mathrm{N}_{2}$ and cooled, $\mathrm{NaHCO}_{3}$ $\left(0.5 \mathrm{~g} \mathrm{l}^{-1}\right)$ and yeast extract $\left(0.2 \mathrm{~g} \mathrm{l}^{-1}\right)$ were added and the $\mathrm{pH}$ was adjusted to $6.8-7.0$ with $6 \mathrm{M} \mathrm{HCl}$ or to 8.3 with $6 \mathrm{M} \mathrm{NaOH}$. The medium was supplemented with amorphous ferric iron oxide $(90 \mathrm{mM})$, which was prepared as described previously (Sokolova et al., 2004). Portions of medium $(10 \mathrm{ml})$ were placed into $50 \mathrm{ml}$ bottles and the 
headspace was filled with $100 \% \mathrm{CO}$ at atmospheric pressure. Bottles were inoculated with approximately $1 \mathrm{~g}$ sample and incubated at $70{ }^{\circ} \mathrm{C}$. After 3 days of incubation, the pressure in the bottles had increased from 140 to 160 $170 \mathrm{kPa}$ at both $\mathrm{pH} 6.8$ and $\mathrm{pH}$ 8.3. In addition, nonmagnetic, brown, amorphous Fe(III) oxide was converted to a black, solid material of less volume that was strongly attracted to a magnet. Pure culture was obtained through serial dilutions on medium supplemented with amorphous $\mathrm{Fe}$ (III) oxide at pH 6.8 under $100 \% \mathrm{CO}$ in the gas phase.

For electron microscopy (negative staining), cultures were fixed as described previously (Sokolova et al., 2002) and examined under a JEM-100B microscope (JEOL). Cells of isolate $1315^{\mathrm{T}}$ were non-motile, straight, short rods, 0.7$1.5 \mu \mathrm{m}$ long and $0.5 \mu \mathrm{m}$ wide (Fig. 1). Cells divided by binary fission (not shown). Spores were not observed.

The effects of temperature and $\mathrm{pH}$ on growth were studied in medium supplemented with Fe(III) or 9,10-anthraquinone 2,6-disulfonate (AQDS), respectively, under a CO atmosphere. Since strain $1315^{\mathrm{T}}$ required amorphous $\mathrm{Fe}(\mathrm{III})$ oxide or AQDS, which are stable only at neutral and alkaline $\mathrm{pH}$, it was impossible to study the growth of the strain under acidic conditions. Growth of strain $1315^{\mathrm{T}}$ occurred within a temperature range of $52-70{ }^{\circ} \mathrm{C}$, with an optimum at $65{ }^{\circ} \mathrm{C}$, and within a $\mathrm{pH}$ range of 5.5-8.5, with an optimum at 6.5-7.2. No growth was observed at 45 or $75{ }^{\circ} \mathrm{C}$, or at pH 5.0 or 8.7. Cell density was determined by direct cell counting. Amorphous $\mathrm{Fe}(\mathrm{III})$ oxide was dissolved before cell counting by threefold dilution of $0.1 \mathrm{ml}$ samples with an ammonium oxalate $\left(28 \mathrm{~g} \mathrm{l}^{-1}\right) /$ oxalic acid $\left(15 \mathrm{~g} \mathrm{l}^{-1}\right)$ solution ( $\mathrm{pH} \mathrm{3.5).}$

Growth of the new isolate on different substrates was tested in medium supplemented with amorphous $\mathrm{Fe}(\mathrm{III})$ oxide or with ferric citrate $(20 \mathrm{mM})$, AQDS $(20 \mathrm{mM})$ or $\mathrm{Na}_{2} \mathrm{~S} .9 \mathrm{H}_{2} \mathrm{O}\left(0.5 \mathrm{~g} \mathrm{l}^{-1}\right)$ under $100 \% \mathrm{~N}_{2}$ in the gas phase. Possible substrates were added to a final concentration of $2 \mathrm{~g} \mathrm{l}^{-1}$. Possible electron acceptors were added to a final concentration of $2 \mathrm{~g} \mathrm{l}^{-1}$ and elemental sulfur was added to $10 \mathrm{~g} \mathrm{l}^{-1}$ in medium reduced with $\mathrm{Na}_{2} \mathrm{~S} .9 \mathrm{H}_{2} \mathrm{O}\left(0.5 \mathrm{~g} \mathrm{l}^{-1}\right)$. $\mathrm{CO}, \mathrm{H}_{2}$ and $\mathrm{CO}_{2}$ were determined by GLC as described previously (Sokolova et al., 2002). Strain $1315^{\mathrm{T}}$ grew

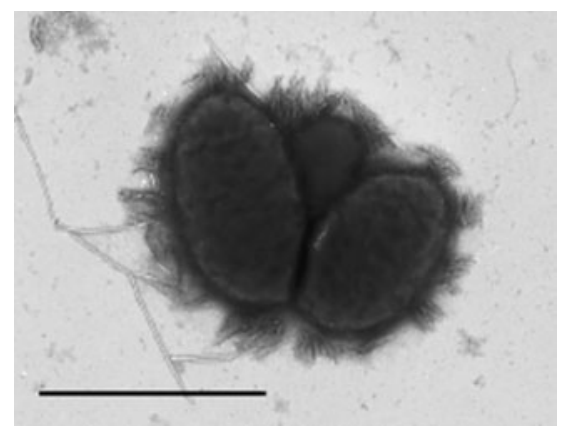

Fig. 1. Electron micrograph of cells of strain $1315^{\top}$. Bar, $1 \mu \mathrm{m}$. chemolithotrophically on $100 \%$ CO only in medium supplemented with $\mathrm{Fe}$ (III) or AQDS. CO uptake was coupled to $\mathrm{H}_{2}$ and $\mathrm{CO}_{2}$ formation according to the equation $\mathrm{CO}+\mathrm{H}_{2} \mathrm{O} \rightarrow \mathrm{CO}_{2}+\mathrm{H}_{2}$. $\mathrm{Fe}(\mathrm{III})$ reduction was monitored by measuring the accumulation of $\mathrm{Fe}(\mathrm{II})$ over time (Fig. 2) as described previously (Slobodkin et al., 1999). Ferric iron was reduced to ferrous iron, and this resulted in magnetite being formed. Yeast extract $(0.2 \mathrm{~g}$ $\left.1^{-1}\right)$ was required for growth. The generation time of strain $1315^{\mathrm{T}}$ for growth on CO under optimal conditions was $9.3 \mathrm{~h}$. No significant reduction of Fe(III) or AQDS in the presence or absence of $\mathrm{CO}$ in sterile medium was observed. No growth, $\mathrm{CO}$ consumption or $\mathrm{H}_{2}$ production occurred in the absence of $\mathrm{Fe}(\mathrm{III})$ or AQDS.

Cell growth of the new isolate and reduction of amorphous $\mathrm{Fe}$ (III) oxide were observed on yeast extract $\left(2.0 \mathrm{~g} \mathrm{l}^{-1}\right)$, glucose, xylose and lactate. With reduction of AQDS, strain $1315^{\mathrm{T}}$ was capable of growing organotrophically with lactate only. Strain $1315^{\mathrm{T}}$ did not utilize peptone, sucrose, galactose, lactose, fructose, formate, acetate, pyruvate, succinate, oxalate, citrate, glycerol or ethanol under all conditions tested. The new isolate also did not grow under a $\mathrm{H}_{2} / \mathrm{CO}_{2}$ atmosphere $(4: 1, \mathrm{v} / \mathrm{v})$ in either the presence or absence of $\mathrm{Fe}(\mathrm{III})$ or AQDS. Strain $1315^{\mathrm{T}}$ did not grow by fermentation of organic substrates in simple medium or in the same medium supplemented with $\mathrm{Na}_{2} \mathrm{~S} \cdot 9 \mathrm{H}_{2} \mathrm{O}$. Several attempts to grow strain $1315^{\mathrm{T}}$ in medium reduced with $\mathrm{Na}_{2} \mathrm{~S} .9 \mathrm{H}_{2} \mathrm{O}$ and supplemented with different electron acceptors (sulfate, thiosulfate, sulfite, sulfur, nitrate or fumarate) and possible electron donors $\left(\mathrm{CO}, \mathrm{H}_{2}\right.$ or lactate) were unsuccessful (Table 1).

Chloramphenicol $\left(100 \mu \mathrm{g} \mathrm{ml}^{-1}\right)$, penicillin $\left(100 \mu \mathrm{g} \mathrm{ml}^{-1}\right)$ and erythromycin $\left(100 \mu \mathrm{g} \mathrm{ml}^{-1}\right)$ inhibited growth, CO oxidation and $\mathrm{Fe}(\mathrm{III})$ reduction completely. Ampicillin $\left(100 \mu \mathrm{g} \mathrm{ml}^{-1}\right)$, streptomycin $\left(100 \mu \mathrm{g} \mathrm{ml}^{-1}\right)$ and tetracycline $\left(100 \mu \mathrm{g} \mathrm{ml}^{-1}\right)$ did not inhibit growth, CO oxidation or $\mathrm{Fe}(\mathrm{III})$ reduction.

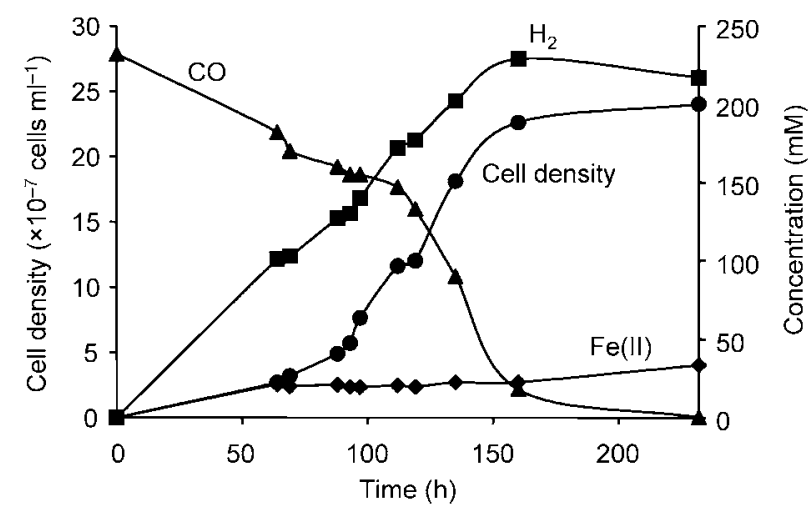

Fig. 2. Growth of strain $1315^{\top}$ at $65{ }^{\circ} \mathrm{C}$ in medium supplemented with amorphous $\mathrm{Fe}$ (III) oxide under an atmosphere of $100 \% \mathrm{CO}$. Concentrations of $\mathrm{CO}$ and $\mathrm{H}_{2}$ are shown as amounts in the gas phase per litre liquid culture. 
Table 1. Characteristics of strain $1315^{\top}$, Carboxydothermus hydrogenoformans $2901^{\top}$ and C. ferrireducens JW/AS-Y $7^{\top}$

Data for reference strains were taken from Svetlichny et al. (1991) (C. hydrogenoformans 2901 ${ }^{\mathrm{T}}$ ) and Henstra \& Stams (2004) and Slobodkin et al. (2006) (data for both strains). None of the strains uses lactate as an electron donor with sulfate as an electron acceptor.

\begin{tabular}{|c|c|c|c|}
\hline Characteristic & C. hydrogenoformans $2901^{\mathrm{T}}$ & C. ferrireducens JW/AS-Y7 $7^{\mathrm{T}}$ & Strain $1315^{\mathrm{T}}$ \\
\hline Morphology & Slightly curved rods & Straight to slightly curved rods & Straight rods \\
\hline Flagellation & Lateral flagella & Peritrichous flagella & Non-motile \\
\hline Range & $40-78$ & $50-74$ & $52-70$ \\
\hline Optimum & $70-72$ & 65 & 65 \\
\hline \multicolumn{4}{|l|}{$\mathrm{pH}$ for growth } \\
\hline Optimum & 7.0 & $6.0-6.2$ & $6.5-7.2$ \\
\hline $\mathrm{G}+\mathrm{C}$ content of DNA $(\mathrm{mol} \%)$ & $39-41$ & 41 & 41.5 \\
\hline \multicolumn{4}{|l|}{$\begin{array}{l}\text { Anaerobic respiration of selected electron } \\
\text { donors and acceptors }\end{array}$} \\
\hline \multicolumn{4}{|l|}{$\mathrm{CO}$ as electron donor with acceptor: } \\
\hline $\mathrm{Fe}(\mathrm{III})$ & - & $+^{*}$ & $+\dagger$ \\
\hline Sulfite & + & + & - \\
\hline Thiosulfate & + & + & - \\
\hline Sulfur & + & + & - \\
\hline Nitrate & + & + & - \\
\hline Fumarate & + & - & - \\
\hline
\end{tabular}

${ }^{\star}$ Growth without $\mathrm{H}_{2}$ production

$\dagger$ Growth with $\mathrm{H}_{2}$ production.

The DNA G + C content was determined by melting-point analysis (Marmur \& Doty, 1962) using Escherichia coli K-12 DNA as a reference. The DNA G $+C$ content in strain $1315^{\mathrm{T}}$ was $41.5 \pm 0.5 \mathrm{~mol} \%$ (mean $\pm \mathrm{SD}$ of three determinations).

The phylogenetic position of the new isolate was determined based on its partial 16S rRNA gene sequence. DNA was isolated from $50 \mu$ cell pellet by a modified alkaline Birnboim-Doly method (Boulygina et al., 2002) and by Wizard technology (Wizard MaxiPreps DNA purification resin; Promega). Selective PCR amplification of the 16S rRNA gene and its sequencing were performed as described previously (Subbotina et al., 2003). Amplification of the template DNA was performed with the modified bacterial forward primer Bact $8-27 \mathrm{~F}\left(5^{\prime}\right.$ AGAGTTTGATCCTGGCTCAG- $3^{\prime}$ ) and the universal reverse primer Univ1492R (5'-TACGGYTACCTTGTTACGACTT-3') as described by Subbotina et al. (2003). Preliminary comparisons (using BLAST) with 16S rRNA gene sequences available in GenBank revealed that isolate $1315^{\mathrm{T}}$ was a member of the phylum Firmicutes, order Clostridiales, family Peptococcaceae. A phylogenetic tree (Fig. 3) demonstrated that strain $1315^{\mathrm{T}}$ was a member of the genus Carboxydothermus, which to date contains two species with validly published names, Carboxydothermus hydrogenoformans (Svetlichny et al., 1991) and Carboxydothermus ferrireducens (Slobodkin et al., 1997, 2006). A direct comparison of the 16 S rRNA gene sequence of strain $1315^{\mathrm{T}}$ with reference sequences of these species was carried out and the level of sequence similarity was found to be $96.4 \%$ with C. ferrireducens JW/AS-Y $7^{\mathrm{T}}$ and

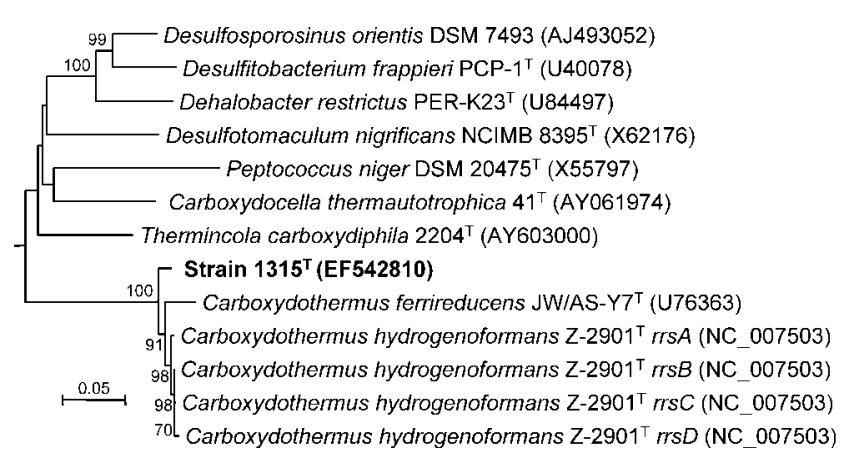

Fig. 3. Phylogenetic tree generated by the neighbour-joining method on the basis of 16S rRNA gene sequences, showing the position of strain $1315^{\top}$. Bar, 0.05 changes per sequence position. Bootstrap values from 100 replications are shown at branch points. 
97.64-97.8\% with four different $16 \mathrm{~S}$ rRNA genes from the total genome of C. hydrogenoformans Z-2901 ${ }^{\mathrm{T}}$. 16S rRNA gene sequence similarity lower than $98.7 \%$ has been used as evidence that organisms belong to different species (Stackebrandt \& Ebers, 2006).

The affiliation of strain $1315^{\mathrm{T}}$ to a novel species is also supported by significant phenotypic differences between strain $1315^{\mathrm{T}}$ and the two previously known species of the genus Carboxydothermus (Table 1). C. hydrogenoformans reduces $\mathrm{Fe}(\mathrm{III})$ with $\mathrm{H}_{2}$ but not $\mathrm{CO}$ and is hydrogenogenic (Svetlichny et al., 1991; Slobodkin et al., 2006), whereas C. ferrireducens reduces $\mathrm{Fe}(\mathrm{III})$ with $\mathrm{CO}$ but without hydrogen production (Slobodkin et al., 2006). Strain $1315^{\mathrm{T}}$ reduces $\mathrm{Fe}(\mathrm{III})$ and grows on $\mathrm{CO}$ with production of $\mathrm{H}_{2}$. Dependence of growth of the strain on the presence of $\mathrm{Fe}(\mathrm{III})$ indicated the dissimilatory nature of $\mathrm{Fe}(\mathrm{III})$ reduction. Ferric iron could be replaced only by AQDS. This physiological feature is common to many other known Fe(III) reducers (Lovley et al., 2004; Slobodkin, 2005). Natural analogues of AQDS (humic acids) are regarded as possible extracellular electron carriers to insoluble $\mathrm{Fe}(\mathrm{III})$ in natural environments (Lovley et al., 2004). Strain $1315^{\mathrm{T}}$ also differed from the two species by several other phenotypic features. The new isolate could not reduce sulfite, thiosulfate, sulfur, nitrate or fumarate, whereas C. hydrogenoformans and C. ferrireducens can reduce these substrates (Henstra \& Stams, 2004). Differences in morphology, temperature and $\mathrm{pH}$ ranges, $\mathrm{G}+\mathrm{C}$ content of DNA and substrates used by the three species in the course of anaerobic respiration are summarized in Table 1. Thus, based on phenotypic and $16 \mathrm{~S}$ rRNA differences, we propose to assign strain $1315^{\mathrm{T}}$ to a novel species of the genus Carboxydothermus, Carboxydothermus siderophilus sp. nov.

\section{Description of Carboxydothermus siderophilus sp. nov.}

Carboxydothermus siderophilus (si.de.ro'phi.lus. Gr. n. sideros iron; Gr. adj. philos loving, N.L. masc. adj. siderophilus iron-loving).

Cells are short, non-motile, straight rods, $0.5 \mu \mathrm{m}$ wide and $0.7-1.5 \mu \mathrm{m}$ long. Gram-positive. Grows at $50-70{ }^{\circ} \mathrm{C}$, with optimum growth at $65{ }^{\circ} \mathrm{C}$, and at $\mathrm{pH} 5.5-8.5$, with optimum growth at $\mathrm{pH}$ 6.5-7.2. Grows only in the presence of $\mathrm{Fe}(\mathrm{III})$ or AQDS. Grows chemoheterotrophically with glucose, xylose, lactate or yeast extract under $\mathrm{N}_{2}$. Grows chemolithotrophically with $\mathrm{CO}$, but not $\mathrm{H}_{2}$. Yeast extract $\left(0.2 \mathrm{~g} \mathrm{l}^{-1}\right)$ is required for growth. During growth on $\mathrm{CO}$ in the presence of $\mathrm{Fe}(\mathrm{III})$ or AQDS, hydrogen, $\mathrm{CO}_{2}$ and $\mathrm{Fe}(\mathrm{II})$ or $\mathrm{AQDSH}_{2}$, respectively, are produced. The product of amorphous Fe(III) oxide reduction is magnetite. No growth occurs with peptone, sucrose, galactose, lactose, fructose, maltose, formate, acetate, pyruvate, succinate, oxalate, citrate, malate, fumarate, glycerol, ethanol or methanol, either in the presence or absence of $\mathrm{Fe}(\mathrm{III})$ or AQDS. Does not reduce sulfate, sulfite, thiosulfate, elemental sulfur, nitrate or fumarate. Growth is inhibited by chloramphenicol, penicillin and erythromycin but not by ampicillin, streptomycin or tetracycline. The DNA G+C content of the type strain is $41.5 \pm 0.5 \mathrm{~mol} \%$.

The type strain, $1315^{\mathrm{T}}\left(=\mathrm{VKPM} 9905 \mathrm{~B}^{\mathrm{T}}=\mathrm{VKM} \mathrm{B}-2474^{\mathrm{T}}\right.$ $=$ DSM $21278^{\mathrm{T}}$ ), was isolated from a terrestrial hot spring of Geyser Valley, Kamchatka Peninsula, Russia.

\section{Acknowledgements}

The authors are grateful to N. A. Kostrikina for preparing the electron micrographs, to A. M. Lysenko for $\mathrm{G}+\mathrm{C}$ content determination and to S. N. Gavrilov for quantitative measurement of Fe(II). This work was supported by grant no. 06-04-49045 from the Russian Foundation for Basic Research.

\section{References}

Boulygina, E. S., Kuznetsov, B. B., Marusina, A. I., Tourova, T. P., Kravchenko, I. K., Bykova, S. A., Kolganova, T. V. \& Galchenko, V. F. (2002). A study of nucleotide sequences of nifH genes of some methanotrophic bacteria. Microbiology (English translation of Mikrobiologiia) 71, 425-432.

Henstra, A. M. \& Stams, J. M. (2004). Novel physiological features of Carboxydothermus and Thermoterrabacterium ferrireducens. Appl Environ Microbiol 70, 7236-7240.

Kevbrin, V. V. \& Zavarzin, G. A. (1992). Effect of sulfur compounds on the growth of the halophilic homoacetic bacterium Acetohalobium arabaticum. Microbiology (English translation of Mikrobiologiia) 61, 563-817.

Lovley, D. R., Holmes, D. E. \& Nevin, K. P. (2004). Dissimilatory $\mathrm{Fe}(\mathrm{III})$ and $\mathrm{Mn}(\mathrm{IV})$ reduction. Adv Microb Physiol 49, 219-286.

Marmur, J. \& Doty, P. (1962). Determination of the base composition of deoxyribonucleic acid from its thermal denaturation temperature. $J$ Mol Biol 5, 109-118.

Slobodkin, A. I. (2005). Thermophilic microbial metal reduction. Microbiology (English translation of Mikrobiologiia) 74, 501-514.

Slobodkin, A. I., Reysenbach, A.-L., Strutz, N., Dreier, M. \& Wiegel, J. (1997). Thermoterrabacterium ferrireducens gen. nov., sp. nov., a thermophilic anaerobic dissimilatory $\mathrm{Fe}(\mathrm{III})$-reducing bacterium from a continental hot spring. Int J Syst Bacteriol 47, 541-547.

Slobodkin, A. I., Tourova, T. P., Kuznetsov, B. B., Kostrikina, N. A., Chernyh, N. A. \& Bonch-Osmolovskaya, E. A. (1999). Thermoanaerobacter siderophilus sp. nov., a novel dissimilatory $\mathrm{Fe}(\mathrm{III})$ reducing, anaerobic, thermophilic bacterium. Int J Syst Bacteriol 49, 1471-1478.

Slobodkin, A. I., Sokolova, T. G., Lysenko, A. M. \& Wiegel, J. (2006). Reclassification of Thermoterrabacterium ferrireducens as Carboxydothermus ferrireducens comb. nov., and emended description of the genus Carboxydothermus. Int J Syst Evol Microbiol 56, 2349-2351.

Sokolova, T. G., Kostrikina, N. A., Chernyh, N. A., Tourova, T. P., Kolganova, T. V. \& Bonch-Osmolovskaya, E. A. (2002). Carboxydocella thermautotrophica gen. nov., sp. nov., a novel anaerobic, CO-utilizing thermophile from a Kamchatkan hot spring. Int J Syst Evol Microbiol 52, 1961-1967.

Sokolova, T. G., Gonzales, J. M., Kostrikina, N. A., Chernyh, N. A., Slepova, T. V., Bonch-Osmolovskaya, E. A. \& Robb, F. T. (2004). Thermosinus carboxydivorans gen. nov., sp. nov., a new anaerobic, thermophilic, carbon-monoxide-oxidizing, hydrogenogenic bac- 
terium from a hot pool of Yellowstone National Park. Int J Syst Evol Microbiol 54, 2353-2359.

Sokolova, T. G., Kostrikina, N. A., Chernyh, N. A., Kolganova, T. V., Tourova, T. P. \& Bonch-Osmolovskaya, E. A. (2005). Thermincola carboxydiphila gen. nov., sp. nov., a novel anaerobic, carboxydotrophic, hydrogenogenic bacterium from a hot spring of the Lake Baikal area. Int J Syst Evol Microbiol 55, 2069-2073.

Sokolova, T. G., Hanel, J., Onyenwoke, R. U., Reysenbach, A.-L., Banta, A., Geyer, R., González, J. M., Whitman, W. B. \& Wiegel, J. (2007). Novel chemolithotrophic, thermophilic, anaerobic bacteria Thermolithobacter ferrireducens gen. nov., sp. nov. and Thermolithobacter carboxydivorans sp. nov. Extremophiles 11, 145-157.

Stackebrandt, E. \& Ebers, J. (2006). Taxonomic parameters revisited: tarnished gold standards. Microbiol Today 36, 152-155.

Subbotina, I. V., Chernyh, N. A., Sokolova, T. G., Kublanov, I. I., Bonch-Osmolovskaya, E. A. \& Lebedinsky, A. V. (2003).
Oligonucleotide probes for the detection of representatives of the genus Themoanaerobacter. Microbiology (English translation of Mikrobiologiia) 72, 331-339.

Svetlichny, V. A., Sokolova, T. G., Gerhardt, M., Ringpfeil, M., Kostrikina, N. A. \& Zavarzin, G. A. (1991). Carboxydothermus hydrogenoformans gen. nov., sp. nov., a CO-utilizing thermophilic anaerobic bacterium from hydrothermal environments of Kunashir Island. Syst Appl Microbiol 14, 254-260.

Wolin, E. A., Wolin, M. J. \& Wolfe, R. S. (1963). Formation of methane by bacterial extracts. J Biol Chem 238, 2882-2886.

Zavarzina, D. G., Sokolova, T. G., Tourova, T. P., Chernyh, N. A., Kostrikina, N. A. \& Bonch-Osmolovskaya, E. A. (2007). Thermincola ferriacetica sp. nov., a new anaerobic, thermophilic, facultatively chemolithoautotrophic bacterium capable of dissimilatory $\mathrm{Fe}(\mathrm{III})$ reduction. Extremophiles 11, 1-7. 